\title{
Impacts of western juniper on plant community composi- tion and structure
}

\author{
RICHARD F. MILLER, TONY J. SVEJCAR, AND JEFFREY A. ROSE
}

Authors are professor of Rangeland Resources Oregon State University and supervisory rangeland scientist, USDA Agricultural Research Service, Eastern Oregon Agricultural Research Center, Burns, Ore. 97720, and fire ecologist, Bureau of Land Management, Burns, Ore. 97720.

\begin{abstract}
Western juniper (Juniperus occidentalis Hook.) has been actively invading shrub steppe communities during the past 120 years. The majority of these stands are still in transition, from early open juniper shrub steppe communities to closed juniper woodlands. In addition, juniper expansion has been occurring across a broad array of soils and topographic positions. Despite the high degree of spatial and developmental heterogeneity, juniper woodlands are frequently treated generically in resource inventories, management, and wildlife habitat assessments. Our goal was to evaluate the impact of western juniper encroachment and dominance on plant community composition and structure across several plant associations. This study was conducted in southeastern Oregon and northeastern California on low sagebrush (Artemisia arbuscula Nutt.), mountain big sagebrush (A. tridentata spp. vaseyana (RYBD.)Beetle), and aspen (Populus tremuloides Michx.) alliances. Stages of woodland development across plant associations were categorized into 1 of 4 successional phases (early, mid, late, and closed) based on tree growth and stand structural characteristics. Plant cover by species group, species diversity and richness, bareground cover, soil characteristics, elevation, aspect, and slope were measured in 108, $60 \times 46$ m macroplots. Twinspan was used to sort plant communities. Regression analysis was used to evaluate the relationship of tree canopy cover to shrub and herbaceous cover. Herbaceous and bareground cover were compared between early and closed stands within plant communities. Woodland structure at stand closure was different among associations varying from $19 \%$ cover and 64 trees $\mathrm{ha}^{-1}$ in a low sagebrush community to $90 \%$ cover and 1,731 trees $\mathrm{ha}^{-1}$ in an aspen community. Increase in juniper dominance had little impact on low sagebrush and an inconsistent effect on bitterbrush (Purshia tridentata Pursh.). In the mountain big sagebrush alliance, sagebrush cover declined to approximately $80 \%$ of maximum potential as juniper increased to about $50 \%$ of maximum canopy cover. Aspen (Populus tremu loides Michx.) also declined as juniper dominance increased. Herbaceous cover and species diversity declined and bare ground increased with increasing juniper dominance in the mountain big sagebrush/Thurber needlegrass association. However, herbaceous cover on the deeper soils characterized by Idaho fescue did not decrease with increasing juniper dominance. To determine
\end{abstract}

This research was supported by the Eastern Oregon Agricultural Research Center (EOARC), and Bureau of Land Management Districts Burns Ore, Lakeview Ore, and area office Alturas Calif, and Modoc National Forest. EOARC is jointly operated by Oregon State University and USDA Agricultural Research Service. The authors wish to thank Lee Eddleman, Robin Tausch, Roger Sheley, Bill Krueger, and 2 anonymous reviewers for their constructive comments.

Oregon State Agricultural Experiment Station Technical Paper Number 11621

Manuscript accepted 6 Mar. 2000. the effect of juniper dominance or woodland management on community composition and structure, plant community and stage of stand development should be identified.

Key Words: Juniperus occidentalis, species composition, plant cover

\section{Resumen}

Durante los 'ltimos 120 años el "Western Juniper" (Juniperus occidentalis Hook.). ha estado invadiendo activamente las comunidades arbustivas de la estepa. La mayoráa de estas poblaciones aun est·n en transición, de comunidades arbustivas de estepa abierta a bosques cerrados de "Juniper". Adem·s, la expansión del "Juniper" ha estado ocurriendo a lo largo de una amplia variedad de suelos y posiciones topogr.ficas. A pesar del alto grado de heterogeneidad espacial y de desarrollo, los bosques de "Juniper" frecuentemente son tratados genéricamente en los inventarios de recursos y evaluaciones de $h \cdot b i t a t y$ manejo de fauna. Nuestra meta fue evaluar el impacto de la invasión y dominancia del "Western Juniper" en la composición y estructura de la comunidad vegetal a lo largo de varias asociaciones de plantas. Este estudio se condujo en el sudeste de Oregon y en el nordeste de California en asociaciones de "Low sagebrush"(Atermisa arbuscula), "Mountain sagebrush" (A. Tridentata spp. vaseyana (Rybd.) Beetle) y “Aspen” (Populus tremuloides Michx). Los estados de desarrollo de los bosques en las asociaciones de plantas se categorizaron en 1 de 4 fases sucesionales (inicial, media, final y cerrada), basadas en el crecimiento de los arboles y las caracterásticas estructurales de la población. La cobertura vegetal por grupo de especies, la diversidad y riqueza de especies, la cobertura de suelo desnudo, las caracterásticas del suelo, elevación y pendiente se midieron en 108 macroparcelas de $60 \times 46 \mathrm{~m}$. Las comunidades de plantas se ordenaron con Twinspan. El an-lisis de regresión se utilizó para evaluar las relaciones de la copa de los arboles con la cobertura de arbustos y estrato herb·ceo. La cobertura de las hierbas y suelo desnudo se comparó entre poblaciones de bosque cerrados e inicial dentro de las comunidades de plantas. La estructura del bosque en poblaciones cerradas difirió entre las asociaciones variando de $19 \%$ de cobertura y 64 arboles ha $^{-1}$ en la comunidad de "Low sagebrush" a 90\% de cobertura y 1,731 arboles ha ${ }^{-1}$ en una comunidad de "Aspen". El aumento en la dominancia del "Juniper" tuvo impacto en la comunidad de "Low sagebrush" y un efecto inconsistente en la comunidad de "Bitterbrush" (Purshia tridentata Pursh.). En la asociación de "Mountain big sagebrush" la cobertura de "Sagebrush" disminuyó a aproximadamente $80 \%$ del maximo potencial conforme el la cobertura de copa del "Juniper" incremento a aproximadamente $50 \%$. El "Aspen" (populus tremu- 
loides Michx.) También se redujo conforme la dominancia del "Juniper" incrementó. En la asociación "Mountain big sagebrush"/"Thuber needlegrass la cobertura de herbeceas y la diversidad de especies disminuyó y la cobertura de suelo desnudo aumento al aumentar la dominancia del "Juniper". Sin embargo, la cobertura herb·cea en suelos profundos, caracterizados por "Ïdaho fescue", no se redujo con el aumento de la dominancia del "Juniper" Para determinar los efectos de la dominancia del "Juniper", o del manejo del bosque, se debe identificar la composición y estructura de la comunidad vegetal y el estado de desarrollo de la población.

Conversion of shrub steppe communities in the Intermountain West to Juniperus woodlands has been an active process during the past 120 years (Tausch et al. 1981, West 1984, Miller and Wigand 1994, West et al. 1998). Over $90 \%$ of the 3.2 million ha of western juniper (Juniperus occidentalis Hook.) woodlands have developed in the last 100 years (USDI-BLM 1990). Prior to European settlement juniper was primarily confined to rocky ridges or surfaces with sparse vegetation (Cottam and Stewart 1940, Barney and Frishknecht 1974, West 1984). However, newly formed juniper woodlands now occupy more productive sites with deep well drained soils (Burkhardt and Tisdale 1969, Tausch et al. 1981, West 1984, Miller and Rose 1995). The replacement of shrub steppe communities with juniper woodland during the past 130 years has been largely attributed to reduced fire frequency (Burkhardt and Tisdale 1976, Miller and Rose 1999). Heavy livestock grazing between 1880 and 1930 removed fine fuels (herbaceous biomass), which previously had carried the fires. In addition, fire suppression, especially following WWII, further reduced the role of fire. Aboriginal Americans may also have impacted juniper and pinyon woodlands over thousands of years through their influence on fire regimes and possibly were partially responsible for the loss of large browsers at the end of the Pleistocene (West 1999).

Western juniper woodlands dominate large areas of land and occupy a broad array of environments. However, despite the heterogeneity of the landscape occupied by juniper and the various stages of stand development occupying these landscapes, juniper woodlands are frequently treated generically in management, resource inventories, and wildlife habitat assessments. There is limited research evaluating the relationship between increasing juniper dominance and associated understory response across different range sites. Most studies on western juniper have addressed fairly specific questions on individual sites (e.g., Adams 1975, Young et al. 1985, Vaitkus and Eddleman 1991, Bates et al. 1998, 2000). It is difficult to compare and contrast existing western juniper research because there is no contextual basis for evaluating stands. Given the diverse landscapes occupied by western juniper, it is very likely that stand development and understory/overstory relations will be strongly influenced by soils, aspect, elevation, etc. In addition, the wide variety of woodland developmental stages occupying these landscapes will also affect composition and structure of the understory. The response of understory vegetation to juniper removal may be entirely different at early versus late stages of stand development. The development of juniper woodlands in sagebrush and aspen communities also alters habitat for wildlife.

There are many classification guides that describe sagebrush steppe and western juniper communities (Driscoll 1964, Franklin and Dyrness 1988, Anderson et al. 1998), yet none provide any detail on western juniper succession. Most of the classification guides attempt to group existing communities, many of which are in early to middle stages of woodland development, rather than describing community dynamics. While classification guides are useful tools for land managers, not recognizing transitional states of juniper encroachment combined with the generic treatment of western juniper woodlands has caused confusion in wildlife habitat evaluations (Maser and Gashwiler 1978, Puchy and Marshall 1993), environmental debates (Belsky 1996), assessments of erosion potential (Buckhouse and Mattison 1980), and general discussions of juniper ecology. Knowledge of community differences, successional patterns, and trajectories are essential for long-term management planning.

This study was designed to provide a context for comparing communities and successional stages associated with western juniper. The objective of the study was to evaluate the influence of juniper dominance on plant community composition and structure across several major plant associations (Grossman et al. 1998) commonly linked with western juniper ${ }^{1}$. Our specific hypotheses were: 1) the impacts of juniper on understory structure and composition varies among associations; 2) at full woodland development, tree densi- ty, and cover are different among associations; and 3) within a plant association there are predictable thresholds of juniper dominance, beyond which disturbance pattern and understory species are negatively impacted.

\section{Materials and Methods}

\section{Study Area}

The study areas were located in the High Desert and Klamath Ecological Provinces in southeastern Oregon and northeastern California (Fig. 1)(latitudes to $43^{\circ} 70^{\prime}$ to $41^{\circ} 00^{\prime}$, longitudes $120^{\circ} 45^{\prime}$ to $118^{\circ} 00$ ) where western juniper typically dominates communities between 1,370 and 2,100 $\mathrm{m}$ in elevation. Parent materials across these 2 provinces are predominately of igneous origin. A combination of basin and range, and weathered mountains of volcanic origin characterize the topography. Climate is cool and semi-arid, characteristic of the northern Intermountain region. Precipitation in the juniper zone across the 2 provinces typically varies between 300 to $400 \mathrm{~mm}$ (Taylor 1993). It is received primarily as snow in November, December, and January, and as rain in March through June.

Plant communities occurring among the 5 study locations (Fig. 1) are characteristic of high desert communities commonly associated with western juniper. Three alliances selected for study were, low sagebrush (Artemisia arbuscula Nutt.), mountain big sagebrush (A. tridentata spp. vaseyana (RYBD.)Beetle), and aspen (Populus tremuloides Michx.) $)^{2}$. Aspen stands were associated with shrub steppe communities in the Steens Mountain and south Warner Mountains study areas below 2,100 m. Study sites spanned from aspen on deep loamy soils to low sagebrush on shallow heavy clay soils, thus providing a variety of communities, soils, landforms, and topographic positions. Elevation of study plots ranged between 1,450 to $2,100 \mathrm{~m}$.

\section{Plot Selection}

To evaluate the effects of juniper succession we substituted space for time by

\footnotetext{
${ }^{1}$ Nomenclature follows physiognomic-floristic hierarchy from Grossman et al. 1998; an alliance is defined by the dominant/diagnostic species of the upper most stratum followed by an association, defined by an additional dominant/diagnostic species from any strata.

${ }^{2}$ Nomenclature follows Hitchcock and Cronquist 1973, and Cronquist et al. 1977.
} 


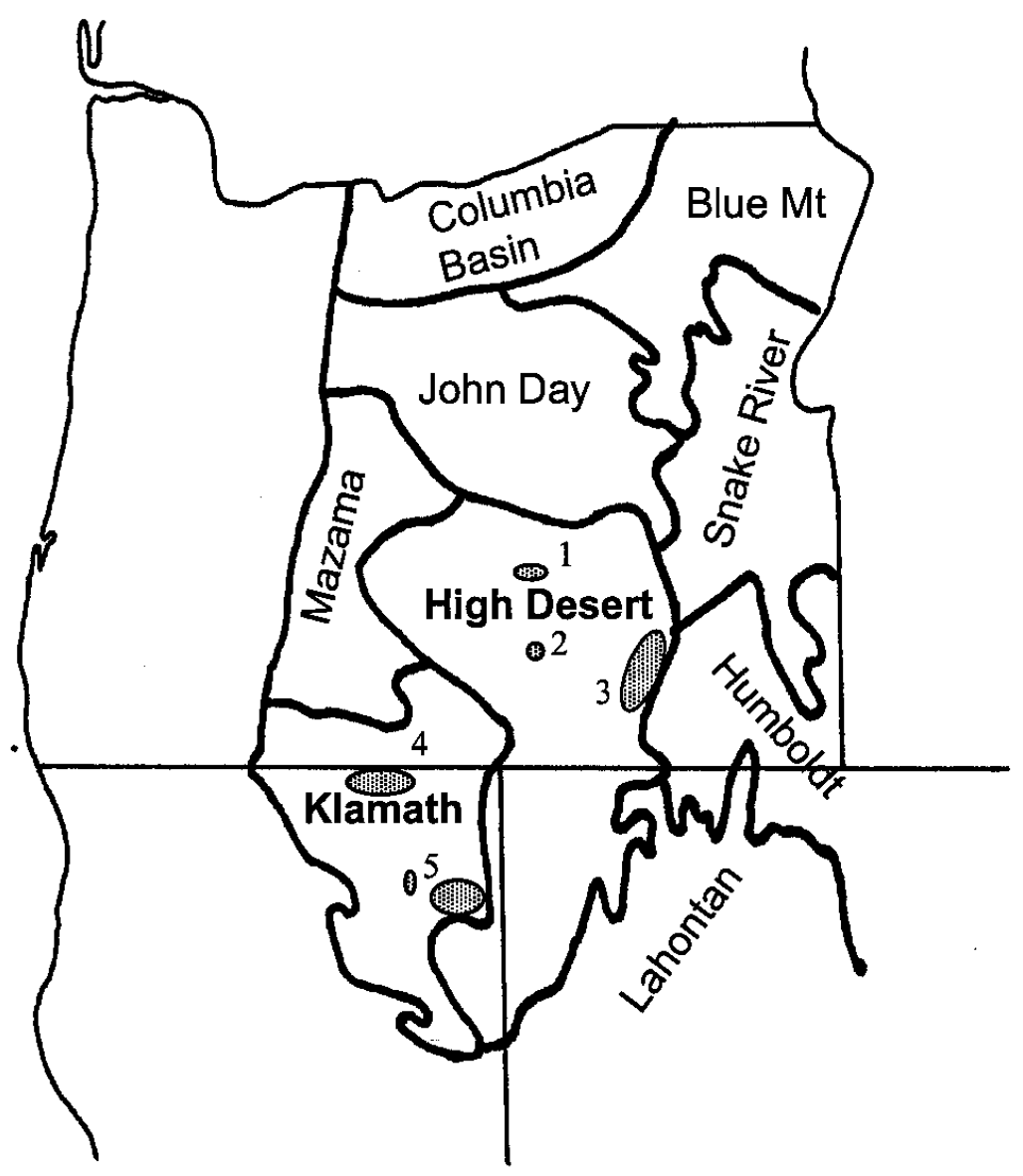

Fig. 1. Five study sites; 1 = Northern Great Basin Experimental Range, $2=$ Juniper Mountain, $3=$ Steens Mountain, $4=$ Devils Garden, and 5 = south Warner Mountains located within the High Desert and Klamath Ecological Provinces (Derived from Anderson et al. 1998, and Bailey 1994). Surrounding provinces are also shown.

evaluating plant communities in different stages of woodland development. We selected stands that represented a large proportion of the 2 ecological provinces and elevations in which western juniper is actively expanding. Stands were grouped into soil and plant associations that dominate much of this landscape, with the primary variable being the relative abundance of western juniper. To reduce variability we attempted to select communities that appeared not to have been significantly altered by heavy grazing or recent fires. Specific criteria used for plot selection were: (1) soils that were common to the area based on existing soil classification maps; (2) communities dominated by low sagebrush, mountain big sagebrush, or aspen with a herbaceous understory dominated by Sandberg bluegrass (Poa sand bergii Vasey) in the low sagebrush alliance; Thurber needlegrass (Stipa thurberiana Piper), bluebunch wheatgrass (Agropyron spicatum Scribn.\& Smith), Idaho fescue (Festuca idahoensis Elmer),
Columbia needlegrass ( $S$. columbiana Macoun), or western needlegrass ( $S$. occi dentalis Thurber) in the mountain big sagebrush alliance; and California brome (Bromus carinatus Hook.\& Arn.) or Letterman's needlegrass ( $S$. lettermanii Vasey) in the aspen alliance; (3) stands that represented different stages of woodland development; (4) sites where disturbance (grazing, weed invasion, roads, etc.) had not significantly altered the community; and (5) sites that had not burned within the last 50 years. The initial classification of plant communities in the field was based on the relative abundance of the species listed above. In closed woodlands, remnant shrubs were used as indicators for community classification. In several aspen macroplots where juniper completely dominated the overstory, the presence of large down dead aspen were used to classify the site. In addition, juniper dominated aspen stands were selected on the basis of having similar soils and topographic position as aspen dominated stands.
Woodland development phases were categorized into 1 of 4 successional phases: early, mid, late, and closed, based on annual tree growth and stand structural characteristics (Miller et al. 1999a). Tree growth characteristics used were annual lateral and terminal leader growth on sapling and full size trees. Stand structure characteristics used were tree cover, height, and proportion of live and dead shrub canopy. The early phase of stand development contained $<5 \%$ juniper cover and sapling juniper $(<3 \mathrm{~m}$ tall $)$ with vigorous lateral and terminal leader growth. Leader growth often exceeded 10 $\mathrm{cm}$ per year. Early development juniper stands also contained a nearly intact shrub layer. The key characteristic for stand closure is limited sapling leader growth, typically $<2 \mathrm{~cm}$ per year. However, terminal leader growth still may exceed $6 \mathrm{~cm}$ per year on canopy dominant trees in late successional and closed stands. We attempted to locate macroplots within each association in the 4 different phases of woodland development. Table 1, derived from Miller et al. (1999a), was modified using data collected in this study.

\section{Plot Measurements}

Plant composition and soil characteristics were measured in 108, 60 x $46 \mathrm{~m}$ macroplots across the 5 study areas (derived from Poulton and Tisdale 1961). Three parallel $60 \mathrm{~m}$ transects located $14 \mathrm{~m}$ apart within each macroplot were used to measure juniper and aspen canopy cover with the line intercept method. Density and height of juniper and aspen $>30 \mathrm{~cm}$ tall were measured in three, $6 \times 60 \mathrm{~m}$ belt transects centered on the $60 \mathrm{~m}$ cover transects. Density of juniper trees $\leq 30 \mathrm{~cm}$ were recorded in a $2 \times 30 \mathrm{~m}$ belt transect also centered on the cover transects. Three, $30 \mathrm{~m}$ lines, located on the $60 \mathrm{~m}$ transect were used to measure shrub cover by species with the line intercept technique. Cover of herbaceous species, litter, bare ground, and rock were estimated in $0.20 \mathrm{~m}^{2}$ plots placed at $3 \mathrm{~m}$ increments along each of the three, $60 \mathrm{~m}$ transects (n $=60 /$ macroplot). We recorded whether a plot was located beneath the tree canopy or in the interspace.

A soil pit was dug near the center of each macroplot. Soils were described and samples collected within each horizon for textural analysis. Soil texture was measured in the laboratory with the hydrometer method of particle size analysis (Gee and Bauder 1986). Aspect, slope, and elevation were also measured. Rill and gullies were noted if present on a site to provide indirect evidence of soil movement. 
Table 1. Characteristics of transitional stages during western juniper woodland succession in several mountain big sagebrush associations. Estimated maximum juniper cover is $\mathbf{2 5 - 4 1 \%}$ in Thurber needlegrass, 34-58\% in Idaho fescue, and $\mathbf{6 0 - 7 5 \%}$ in Columbia needlegrass associations.

\begin{tabular}{|c|c|c|c|c|}
\hline $\begin{array}{l}\text { Characteristics } \\
\text { (Post Settlement Stands) }\end{array}$ & Early & Mid & Late & Closed \\
\hline $\begin{array}{c}\text { Tree Canopy } \\
\text { (\% of Max Potential) }\end{array}$ & $\begin{array}{c}\text { Open, actively expanding } \\
\leq 10 \%\end{array}$ & $\begin{array}{l}\text { Actively expanding } \\
10 \text { to } 49 \%\end{array}$ & $\begin{array}{l}\text { Expansion reduced } \\
50 \text { to } 80 \%\end{array}$ & $\begin{array}{c}\text { Expansion nearly stabilized } \\
>80 \%\end{array}$ \\
\hline $\begin{array}{l}\text { Potential Berry } \\
\text { production }\end{array}$ & Low & Moderate to high & Low to moderate & Low to near absent \\
\hline Tree Recruitment & Active & Active & $\begin{array}{c}\text { Reduced, limited primarily to } \\
\text { beneath trees }\end{array}$ & Absent \\
\hline
\end{tabular}

${ }_{2}^{1}$ During the late and closed stages of succession, leader growth in mature trees is usually confined to the upper $1 / 3$ of the canopy.

${ }^{2}$ Crown lift is the mortality of lower tree limbs usually due to shading from neighboring trees.

\section{Analyses}

Twinspan, a two-way indicator of species analysis, was used to verify and resort initial classification of communities made in the field (Gauch 1982). The grouping of communities into associations was based on relative plant species abundance using cover data. Assimilation tables were developed to describe plant assemblages and physical characteristics for each community. Regression analyses was used to evaluate the relationship of tree canopy cover to shrub and herbaceous canopy cover. A student-t test was used to compare herbaceous and bareground cover in the tree interspace between early and closed juniper stands within an associa- tion. We conducted analyses on associations with at least 3 macroplots in each of the early and closed transitional stages. Hill's diversity indices, species number (N0), Shannon's index (N1), and Simpson's index (N2), were calculated for early and closed stands using cover data. Neither mountain big sagebrush nor western juniper were included in diversity and richness indices. Mean diversity indices for macroplots in open and closed stands within associations are reported. ANOVA and Duncan's New Multiple Range Test were used to compare juniper canopy cover and density at stand closure between associations (SAS 1996).

\section{Results}

\section{Associations}

Twinspan separated out several major associations (Table 2). Low sagebrush/Sandberg bluegrass: This association was typically found on clayey montmorillinitic frigid Lithic Argixerolls ranging between 20 and $60 \mathrm{~cm}$ deep underlain by fractured basalt. Several sites were also classified as Lithic Durargids. Slopes were $<2 \%$. Herbaceous species characterizing this association were Sandberg bluegrass, onespike oatgrass (Danthonia unispicata (Thurb.) Munro ex Macoun), Idaho fescue (beneath the juniper canopies), nineleaf

Table 2. Plant associations sampled where $\mathbf{n}>3$. Groupings were done by $\mathbf{T w i n s p a n}($ total $\mathbf{n}=\mathbf{1 0 8}$ ).

\begin{tabular}{|c|c|c|c|c|c|}
\hline Association & Sample size & $\begin{array}{c}\text { Elevation } \\
\text { Range (mean) }\end{array}$ & $\begin{array}{c}\text { General } \\
\text { Aspect }\end{array}$ & Slope & $\begin{array}{c}\text { Soils } \\
\text { A \& B Horizons }\end{array}$ \\
\hline $\begin{array}{l}\text { Low sagebrush/Sandberg } \\
\text { bluegrass }\end{array}$ & 12 & $\begin{array}{c}(\mathrm{m}) \\
1482-1824 \\
(1626)\end{array}$ & None & $\begin{array}{c}(\%) \\
<2\end{array}$ & $\begin{array}{l}\text { A: Shallow clay loam to clay } \\
\text { B: clay }\end{array}$ \\
\hline $\begin{array}{l}\text { Mountain big sagebrush/ } \\
\text { Thurber needlegrass }\end{array}$ & 15 & $\begin{array}{l}1575-1990 \\
(1737)\end{array}$ & Southerly & $8-22$ & $\begin{array}{l}\text { A: Sandy clay loam to clay loam } \\
\text { B: Sandy clay loam to silty clay loam }\end{array}$ \\
\hline Idaho fescue & 49 & $\begin{array}{l}1525-2006 \\
(1723)\end{array}$ & $\begin{array}{l}\text { Northwest to } \\
\text { Southeast }\end{array}$ & $0-45$ & $\begin{array}{l}\text { A: Loam to clay loam } \\
\text { B: Clay loam to clay }\end{array}$ \\
\hline $\begin{array}{l}\text {-Mountain snowberry/ } \\
\text { Columbia needlegrass }\end{array}$ & 12 & $\begin{array}{l}1560-2100 \\
(1846)\end{array}$ & $\begin{array}{l}\text { Northwest } \\
\text { to Northeast }\end{array}$ & $10-25$ & A\&B: Loam \\
\hline Quaking aspen & 15 & $\begin{array}{l}1780-2045 \\
(1906)\end{array}$ & North to East & $8-35$ & A\&B: Loam \\
\hline
\end{tabular}


lomatium (Lomatium triternatum (Pursh) Coult.\& Rose), scabland penstemon (Penstemon duestus Dougl. Ex Lindl.), white paintbrush (Castilleja pilosa (Wats.) Rydb.), and ballhead sandwort (Arenari conjestus Nutt.).

Mountain big sagebrush/Thurber needlegrass: This was the driest of the mountain big sagebrush communities sampled, typically occurring on southerly aspects. This association was commonly found on loamy, sandy loam, and fineloamy, skeletal mixed frigid Argixerolls. Soil varied between 36 and $67 \mathrm{~cm}$ in depth across the macroplots, and were frequently underlain by a duripan. Bluebunch wheatgrass ranged from a trace to co-dominating with Thurber needlegrass. Common forbs were tailcup lupine (Lupinus cauda tus Kell.), basalt milkvetch (Astragalus fil ipes Torr.), Hoods phlox (Phlox hoodii Rich.), western hawksbeard (Crepis occi dentalis Nutt.), sagebrush mariposa (Calochortus macrocarpa Dougl.), and nineleaf lomatium.

Mountain big sagebrush/Bluebunch wheatgrass: This association occurred on south to west facing slopes on well drained to moderately drained soils. Soil depths varied between 45 and $80 \mathrm{~cm}$. Common forbs were similar to those found in the Thurber needlegrass communities.

Mountain big sagebrush/Idaho fescue: Soils commonly found in this association were loamy to clayey, skeletal, mixed to montmorillintic Typic to Pachic Argixerolls. Soil depths ranged between 65 and $100+\mathrm{cm}$. On Steens Mountain the majority of these communities were located on northerly aspects, particularly below $1,800 \mathrm{~m}$. However, a few plots were located on southerly aspects. On the Devils Garden, slopes were typically less than $10 \%$ with mixed aspects. Herbaceous species common in this association were prairie junegrass (Koeleria cristata Pers.), twin arnica (Arnica sororia Greene), nodding microseris (Microseris nutans (Geyer) Schultz-Bip.), common yarrow (Achillea millifolium L.), parsnip-flowered eriogonum (Eriogonum heracleoides Nutt.), onestemmed butterweed (Senecio integerrimus Nutt.), and speckle-pod milkvetch (Astragalus lentiginosus Dougl.). Twinspan further divided this association into 3 subgroups. The first division separated south Warners from the Devils Garden and the Oregon study sites (see Figure 1 for locations). The second division separated the Devils Garden study area from the Oregon study sites. Soils were similar across the 3 subgroups. However several unique species distin- guished the 3 subgroups. Species distinguishing south Warners were woolly mule's ear (Wyethia mollis Gray), barestem buckwheat (Eriogonum nudum Doug1.), wavy-leaved paintbrush (Castilleja applegatei Fern.), desert gooseberry (Ribes velutinum Greene), and spurred lupine (Lupinus laxiflorus Dougl.). The relatively low abundance of forbs in the Devils Garden macroplots compared to the Oregon study sites was the primary difference separating these 2 subgroups.

Mountain big sagebrush-mountain snowberry (Symphoricarpos oreophis Gray)/Columbia needlegrass (western needlegrass): This association, typically located on northerly aspects with deep loamy soils, was the most productive of the mountain big sagebrush associations sampled. This association also had the greatest diversity of shrubs compared to other communities. Soils were generally loamy mixed frigid Pachic Haploxerolls, > $80 \mathrm{~cm}$ deep. The dominant understory grass characterizing this association on Steens Mountain, Columbia needlegrass, shifted to western needlegrass in the south Warner study area. Common herbaceous species in this association were California brome, Ross' sedge (Carex rossii Boot), short-beaked agoseris (Agoseris glauca (Pursh) Raf.), one-stemmed butterweed, nodding microseris, long-flowered bluebells (Mertensia longiloba Greene), and ballhead waterleaf (Hydorphyllum capita tum Dougl.).

Quaking aspen: These stands were situated on north to northeast aspects and were the most mesic of the rangeland cover types measured. Soils were typically loamy to fine-loamy mixed frigid Pachic

Table 3. Mean and range of juniper cover and density (trees $>3 \mathrm{~m}$ tall) in closed stands for 6 associations. Means followed by different letters were significantly different $(p<0.0001)$ for cover or density between associations.

\begin{tabular}{|c|c|c|}
\hline Association & $\begin{array}{l}\% \text { Cover } \\
\text { (range) }\end{array}$ & $\begin{array}{l}\text { Trees } \mathrm{Ha}^{-1} \\
\text { (range) }\end{array}$ \\
\hline $\begin{array}{l}\text { Low sagebrush/Sandberg } \\
\text { bluegrass }(n=4)\end{array}$ & $\begin{array}{c}(\%) \\
21^{\mathrm{a}} \\
(19-24)\end{array}$ & $\begin{array}{c}84^{\mathrm{a}} \\
(64-111)\end{array}$ \\
\hline $\begin{array}{l}\text { Mountain big sagebrush/ } \\
\text { Thurber needlegrass }(n=6)\end{array}$ & $\begin{array}{c}34^{\mathrm{b}} \\
(25-41)\end{array}$ & $\begin{array}{c}346^{\mathrm{b}} \\
(222-481)\end{array}$ \\
\hline $\begin{array}{l}\text { Mountain big sagebrush/ } \\
\text { bluebunch wheatgrass }(n=2)^{1}\end{array}$ & $\begin{array}{c}43 \\
(35-47)\end{array}$ & $\begin{array}{c}345 \\
(260-444)\end{array}$ \\
\hline $\begin{array}{l}\text { Mountain big sagebrush/ } \\
\text { Idaho fescue }(n=15)\end{array}$ & $\begin{array}{c}48^{\mathrm{c}} \\
(34-58)\end{array}$ & $\begin{array}{c}479^{c} \\
(247-716)\end{array}$ \\
\hline $\begin{array}{l}\text { Mountain big sage-- } \\
\text { brush- snowberry/Columbia } \\
\text { needlegrass }(n=1)^{1}\end{array}$ & 63 & 889 \\
\hline Quaking aspen $(n=3)$ & $\begin{array}{c}84^{\mathrm{d}} \\
(78-90)\end{array}$ & $\begin{array}{c}1319^{\mathrm{d}} \\
(906-1731)\end{array}$ \\
\hline
\end{tabular}

${ }^{1}$ Not included in analysis because $\mathrm{n}<3$.
Haploxerolls to Haplocryolls, > $100 \mathrm{~cm}$ in depth. Common understory species were California brome, Letterman's needlegrass, bearded wheatgrass (Agropyron caninum (L.) Beauv.), Menzie's silene (Silene meziesii Hook.), nodding microseris, ballhead waterleaf, veiny meadowrue (Thalictrum venulosum Trel), and starry solomon (Smilacina stellata (L.) Desf.).

\section{Closed woodland structure}

Both cover and density of juniper trees $(>3 \mathrm{~m})$ at stand closure were significantly different ( $\mathrm{p} \leq 0.0001)$ across associations (Table 3 ). Woodland canopy cover of closed stands ranged as low as $19 \%$ in a low sagebrush/Sandberg bluegrass community to a high of $90 \%$ in an aspen community. Tree density also varied widely across communities ranging between 64 and 1,731 trees ha ${ }^{-1}$ in closed stands. As woodland development approached stand closure, maximum density of young trees ( $<3 \mathrm{~m}$ in height) declined (Fig. 2).

\section{Shrub and aspen canopy}

The relationship between low sagebrush and juniper canopy cover was not significant ( $p>0.05)$. The only area where low sagebrush was noticeably absent was directly beneath the juniper canopy. However, there was a strong relationship between juniper and mountain big sagebrush canopy cover (Fig. 3). As juniper canopy cover increased mountain big sagebrush canopy declined. When juniper canopies reached $50 \%$ of maximum woodland cover, the shrub layer declined to $80 \%$ of maximum potential in the moun- 


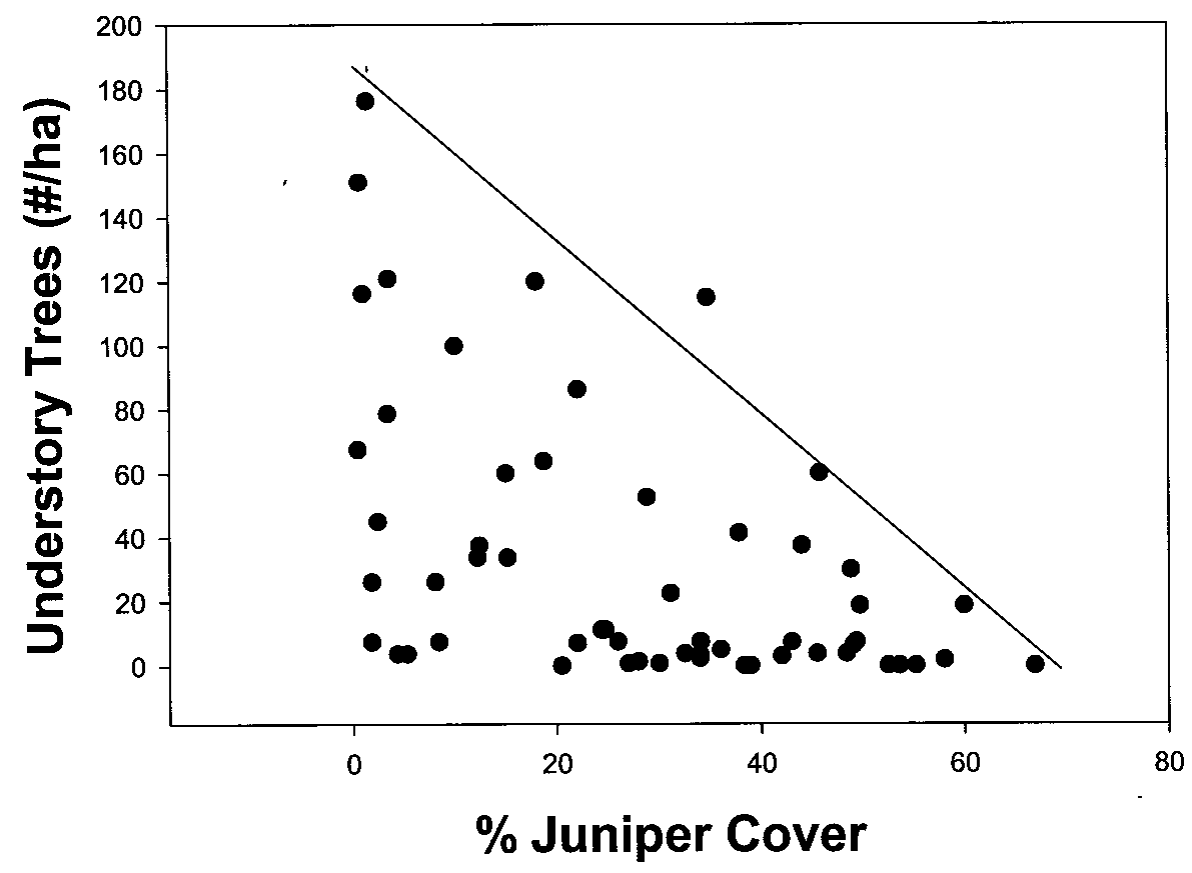

Fig. 2. The relationship between understory juniper tree density (trees $<3 \mathrm{~m}$ tall) and mature overstory tree canopy cover for the mountain big sagebrush/Idaho fescue association. The line represents a boundary layer of maximum juvenile juniper trees occurring with varying juniper overstory canopy cover.

tain big sagebrush/Thurber, mountain big sagebrush/Idaho fescue, and mountain big sagebrush-snowberry/Columbia needlegrass associations. Limited cover values and high variability for other shrub species made it difficult to evaluate their relationship with juniper cover. However, for the more frequently occurring species, increasing juniper cover appeared to have little effect on mountain snowberry and wax current (Ribes cereum Dougl.) in mountain big sagebrush-snowberry/Idaho fescue or aspen communities. We did not observe an increase in dead skeletons for these 2 species as juniper canopy increased. The response of bitterbrush (Purshia tridentata Pursh) to increasing juniper dominance was inconsistent. Several closed juniper stands contained $80 \%$ dead bitterbrush, while 3 closed stands showed little bitterbrush mortality and active recruitment. We measured only 2 curlleaf mountain-mahogany (Cercocarpus ledifolius Nutt.) stands that contained a closed juniper canopy. In both stands > $90 \%$ of the curlleaf mountain-mahogany canopy was dead.

There was a very strong inverse relationship between juniper and aspen overstory canopy cover ( $\mathrm{p}<0.0001)$ and density ( $\mathrm{p}<0.003$ ) (Fig. 4). As juniper overstory canopy increased, aspen saplings did not replace dying aspen overstory trees.

\section{Herbaceous understory and bare- ground}

Response of herbaceous understory cover to juniper was different among associations. In the low sagebrush/Sandberg bluegrass association herbaceous cover

Table 4. Perennial herbaceous cover (\%) and sample size for early and closed stages of woodland development across associations.

\begin{tabular}{|c|c|c|c|c|c|}
\hline Association & Early & $\mathrm{n}$ & Closed & $\mathrm{n}$ & $\mathrm{p}$ \\
\hline & (\% cover) & & (\% cover) & & \\
\hline $\begin{array}{l}\text { Low sagebrush/Sandberg } \\
\text { bluegrass }\end{array}$ & & 5 & & 4 & \\
\hline P. Grass & 8 & & 11.1 & & ns \\
\hline P. Forb & 4.1 & & 4.4 & & ns \\
\hline Total & 12.1 & & 16.5 & & ns \\
\hline $\begin{array}{l}\text { Mountain big sagebrush/Thurber } \\
\text { needlegrass }\end{array}$ & & 5 & & 7 & \\
\hline P. Grass & 14 & & 4 & & .001 \\
\hline P. Forb & 2 & & 1 & & $\mathrm{~ns}$ \\
\hline Total & 16 & & 5 & & .001 \\
\hline $\begin{array}{l}\text { Mountain big sagebrush/Idaho } \\
\text { fescue Devils Garden }\end{array}$ & & 6 & & 9 & \\
\hline P. Grass & 7.8 & & 9.9 & & $\mathrm{~ns}$ \\
\hline P. Forb & 2.1 & & 1.1 & & ns \\
\hline Total & 9.9 & & 11 & & ns \\
\hline $\begin{array}{l}\text { Mountain big sagebrush/Idaho } \\
\text { fescue Steens }\end{array}$ & & 9 & & 6 & \\
\hline P. Grass & 16 & & 15 & & ns \\
\hline P. Forb & 16.5 & & 12 & & ns \\
\hline Total & 32.5 & & 27 & & ns \\
\hline Quaking aspen & & 8 & & 3 & \\
\hline P. Grass & 9.5 & & 4.4 & & ns \\
\hline P. Forb & 5 & & 7.3 & & ns \\
\hline Total & 14.5 & & 11.7 & & ns \\
\hline
\end{tabular}

was not different between early stands and stands with maximum juniper cover (Table 4). However, closed juniper stands in the low sagebrush/Sandberg bluegrass association did not fit the criteria developed in Table 1. It was difficult to determine if this association was near maximum juniper cover at $21 \%$. Perennial grass dominance shifted from Sandberg bluegrass in the interspace to Idaho fescue beneath the juniper canopy where grass cover typically exceeded $65 \%$.

Herbaceous cover in the tree interspace in the mountain big sagebrush/Thurber needlegrass association was $69 \%$ less $(\mathrm{p}<$ $.001)$ in closed juniper woodlands compared to early stands (Table 4). The perennial grass component was significantly less in closed versus early stands. Perennial forbs as a group accounted for $\leq 2 \%$ of the ground cover, were highly variable, and were not significantly different between open and closed stands. There was a significant relationship $\left(r^{2}=0.865, p \leq 0.0001\right)$ between juniper and total perennial herbaceous cover in this association (Fig. 5). When juniper cover reached $50 \%$ of the predicted maximum, perennial herb cover declined to $5.7 \%$.

Herbaceous cover in the tree interspace was not different between early and closed mountain big sagebrush/Idaho fescue juniper stands at Steens, Juniper Mountain, and Devils Garden study areas (Table 4). 


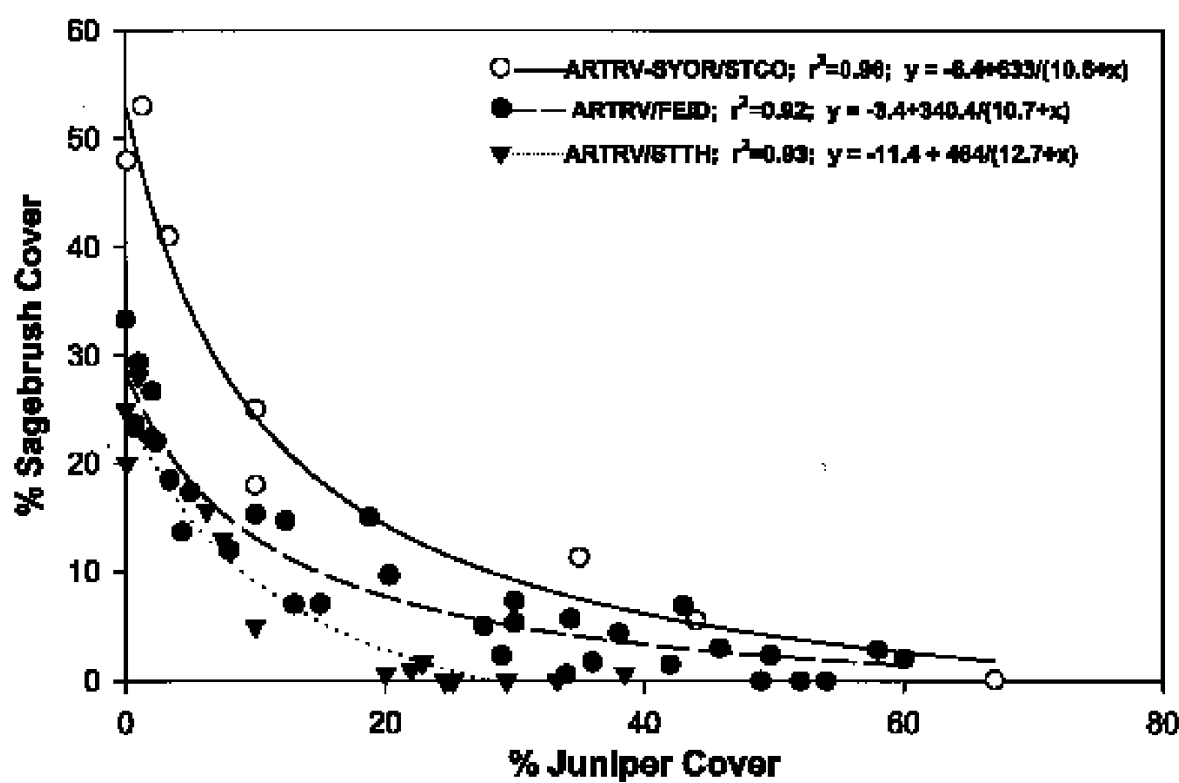

Fig. 3. The relationship between juniper and mountain big sagebrush cover for the mountain big sagebrush/Thurber needlegrass (ARTRV/STTH), mountain big sagebrush/ Idaho fescue (ARTRV/FEID), and mountain big sagebrush-snowberry/Columbia needlegrass (ARTRV-SYOR/STCO) associations.

Nor was there a difference between perennial grass or forb cover between closed and early woodlands. We were unable to locate closed stands within this association in the South Warner study area where woodlands ranged from early to mid development within this association. Regression analysis also showed no significant relationship between juniper cover and herbaceous cover across the different stages of woodland development in the mountain big sagebrush/Idaho fescue and mountain big sagebrush-snowberry/Columbia needlegrass communities.

There was no significant difference in herbaceous cover in aspen stands where juniper was in the early stages of encroachment compared to stands where juniper dominated the overstory. The lack of significance was probably due to the high degree of variability in herb cover across aspen stands regardless of juniper abundance. However, in one aspen macroplot containing nearly 1,000 juniper trees $\mathrm{ha}^{-1}$ and heavy needle deposition due to crown lift (leaf canopy lifts from the ground due to lower limb mortality), perennial herb cover accounted for only $2 \%$. The most abundant herbs in this stand were 4 annuals, pink microsteris (Migrostis gracilis Hook.), small-flowered blue-eyed Mary (Collinsia parviflora Lindl.), smallflowered woodlandstar (Lithophragma parviflora (Hook.) Nutt.), and miner's lettuce (Montia perfoliata (Donn) Howell).
Percent bare ground was consistent with herbaceous cover results (Table 5). Percent bare ground was not greater in the tree interspace between closed stands and early stands of woodland development across the low sagebrush/Sandberg bluegrass, mountain big sagebrush/Idaho fescue, and aspen associations. However, in the mountain big sagebrush/Thurber needlegrass association bareground in the tree interspace was significantly greater in the closed stands compared to early woodlands.

\section{Diversity}

Species diversity indices were consistently lower in closed juniper woodlands in the mountain big sagebrush/Thurber needlegrass association compared to woodlands in the early development stage
(Table 6). Indices appeared similar between early and closed stands in the low sagebrush/Sandberg bluegrass, and aspen communities, and mountain big sagebrush/Idaho fescue Oregon subgroup. However, the mountain big sagebrush/Idaho fescue for the Devils Garden subgroup was not consistent with the Oregon sites. Species diversity indices, $\mathrm{N} 1$ and $\mathrm{N} 2$, were lower in the closed stages of woodland development compared to the early phase. This may be due to an increase in perennial grass dominance and a decline in forb abundance under closed stands.

\section{Discussion}

The need for sound information on western juniper succession arises from the fact that the majority of western juniper woodlands have not yet reached full development. In addition, this species is still rapidly expanding its range. Gedney et al. (1999) reported that $65 \%$ of the 0.9 million ha of western juniper woodland in Oregon had less than $30 \%$ tree canopy cover. An additional 1.1 million ha of western juniper were classified as savanna $(<10 \%$ tree cover). If juniper woodland canopy cover can potentially exceed $30 \%$ in many mountain big sagebrush associations and $20 \%$ in low sagebrush associations at stand closure this would indicate that the majority of the 2 million ha of western juniper in Oregon are still in transition from shrub steppe to juniper woodland.

\section{Stand Development}

The lack of a well-defined system for identifying stage of stand development has contributed to controversies over western juniper ecology and management. For example, during early stages of stand development with low tree cover $(<5 \%)$, mountain big sagebrush cover is still an

Table 5. Percent bareground in the tree interspace for 5 associations.

\begin{tabular}{|c|c|c|c|c|c|}
\hline \multirow[t]{2}{*}{ Association } & \multicolumn{4}{|c|}{ Cover } & \multirow[b]{2}{*}{ Prob } \\
\hline & Open & $\mathrm{n}$ & Closed & $\mathrm{n}$ & \\
\hline & $(\%)$ & & $(\%)$ & & \\
\hline $\begin{array}{l}\text { Low sagebrush/Sandberg } \\
\text { bluegrass }\end{array}$ & 56 & 5 & 54 & 4 & ns \\
\hline $\begin{array}{l}\text { Mountain big sagebrush/ } \\
\text { Thurber needlegrass }\end{array}$ & 55 & 5 & 90 & 7 & .001 \\
\hline $\begin{array}{l}\text { Mountain big sagebrush/ } \\
\text { Idaho fescue (Devils Garden) }\end{array}$ & 34 & 6 & 32.4 & 9 & ns \\
\hline $\begin{array}{l}\text { Mountain big sagebrush/ } \\
\text { Idaho fescue (Steens) }\end{array}$ & 16 & 9 & 18 & 6 & $\mathrm{~ns}$ \\
\hline Quaking aspen & 5 & 8 & 3.8 & 3 & $\mathrm{~ns}$ \\
\hline
\end{tabular}



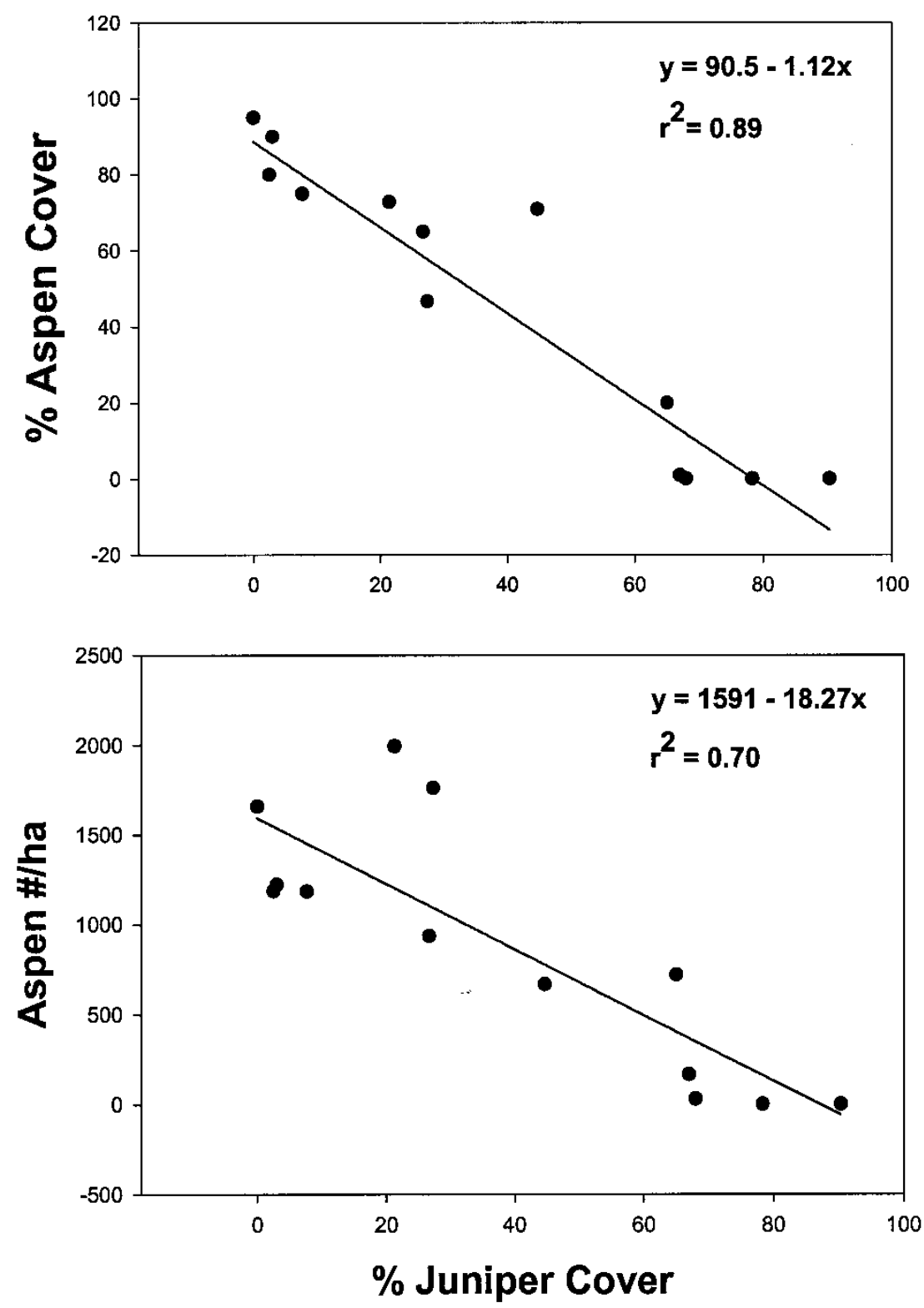

Fig. 4. The relationship between juniper canopy cover and aspen canopy cover $(p<0.0001)$ and density $(p<0.003)$.

important component in the understory providing structural diversity (Fig. 3). However, as juniper cover increases to half of its maximum potential for the site, mountain big sagebrush cover is reduced by $80 \%$. Thus, in a discussion of juniper impacts on sagebrush cover, it is critical to define both the stage of stand development and plant community involved. There appear to be repeatable stand characteristics in the mountain big sagebrush alliance that can be used to define the stage of stand development, regardless of association and site potential (Table 1). Many of the characteristics used in Table 1 relate to the degree of site domination by western juniper. As juniper increases in domi- nance, woody species such as mountain big sagebrush, bitterbrush, mountain mahogany, and aspen decline (Figs. 3 and 4), and intraspecific competition reduces leader growth and berry production of juniper. There is also a reduction in juniper recruitment as stand development progresses (Fig. 2).

During woodland succession the decline in mountain big sagebrush canopy is not proportional to the increase in juniper canopy. As juniper approaches $50 \%$ of maximum potential canopy cover in mountain big sagebrush communities, mountain big sagebrush declines to about one fifth of maximum canopy cover (Fig. 3 ). In southwest Utah pinyon-juniper com- munities, Tausch and West (1995) reported shrubs declined to one fourth of maximum when pinyon-juniper cover reached $50 \%$ of maximum. Throughout the Intermountain West, big sagebrush has been reported to decline with the increase in juniper or pinyon (Cottam and Stewart 1940, Adams 1975, West 1984, Tress and Klopatek 1987, Tausch and West 1995). Although we measured a decline in bitterbrush canopy and an increase in shrub skeletons with the increase of juniper, the response of bitterbrush was not consistent. In central Oregon, Adams (1975) reported a decline in big sagebrush, bitterbrush, and rabbitbrush (Chrysothamnus viscidiflours) with an increase in western juniper canopy. However, Adams concluded that existing plants of bitterbrush lived out their normal life span during woodland development but recruitment was drastically limited. We observed both scenarios of limited and active bitterbrush recruitment under closed stands. Juniper also readily invaded aspen stands. Both aspen density and cover declined as juniper canopy cover increased. In the absence of fire, juniper will likely continue to invade and replace aspen stands within the juniper woodland belt, below 2,130 m (Miller and Rose 1995, Wall 1999).

In our study, the response of herbaceous species to increasing juniper dominance was not consistent. In the literature, the report of declining native herbaceous vegetation as juniper and or pinyon increases is generally consistent (Arnold 1964, Blackburn and Tueller 1970, Meeuwig and Cooper 1981, Tausch et al. 1981, Everett and Sharrow 1985, Tausch and West 1995). However, the majority of these studies were conducted on heavily disturbed sites. One exception, a study conducted on a site with a past history of over-grazing, found an increase in herbaceous production with increased tree size (Vitakus and Eddleman 1991). However, in northwestern California, Evans and Young (1985) found that evaluating the effect of western juniper on the herbaceous understory was difficult because of past heavy grazing and the dominance of introduced annuals. In our study, stands were lightly to moderately disturbed and weed invasion was minimal. In this region the threat of weed invasion is generally thought to be greatly reduced above $1500 \mathrm{~m}$. The response of herbaceous plant cover in the mountain big sagebrush/Thurber needlegrass association fit the hypothesis that understory vegetation declines as tree dominance increases. The majority of these soils have a restrictive layer between 


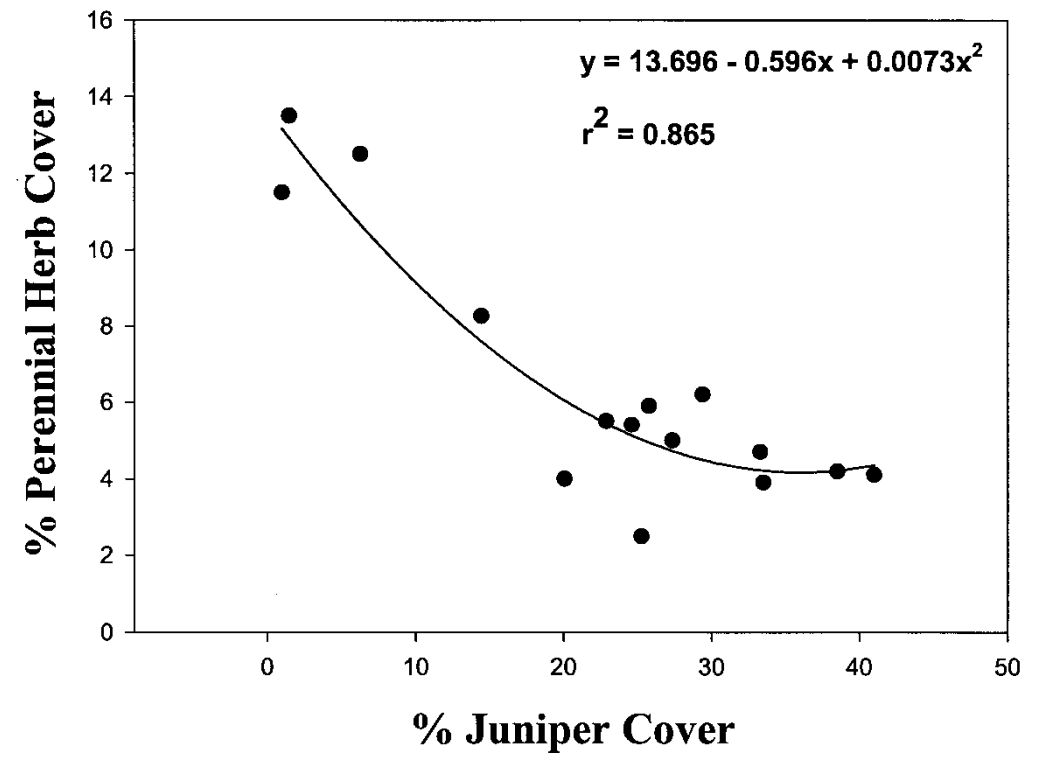

Fig. 5. The relationship between perennial herb and juniper cover in the mountain big sagebrush/Thurber needlegrass association.

30 and $50 \mathrm{~cm}$ deep. We observed a very high density of juniper roots in the soil layer above the duripan in our soil pits. Few roots were observed to penetrate the duripan. In this same association, Bates et al. (2000) reported a 3 fold increase in herbaceous cover during the second growing season following western juniper removal. The soils on this study site were 40 to $50 \mathrm{~cm}$ deep underlain by a thick duripan, which limited root penetration. However, in the mountain big sagebrush/Idaho fescue association, herbaceous cover between early and closed woodlands was similar. These sites occupied deeper soils underlain by fractured bedrock. In the soil pits, we observed a lower concentration of juniper roots in the upper $50 \mathrm{~cm}$. The lack of herbaceous response to increasing juniper may also be partially attributed to Idaho fescue being well adapted to growing beneath conifer canopies. Unfortunately we were unable to locate enough late to closed woodlands in the Columbia needlegrass association to determine if deep well drained soils and/or species adaptability is the key to the persistence of the herb layer. Herbaceous composition and cover in aspen stands was highly variable. However, in a stand dominated by juniper where heavy conifer needle deposition occurred due to crown lift, herbaceous cover was $2 \%$ and primarily composed of annuals. Wall (1999) reported a significant decrease in herbaceous cover as juniper dominance increased in aspen stands.

The amount of bareground in the tree interspace was greater in closed stands compared to earlier stages of development only in the mountain big sagebrush/Thurber needlegrass association. Although juniper cover averaged $34 \%$ in closed stands, little plant or litter cover protected the interspace, which accounted for $66 \%$ of the total area. We observed considerably more surface soil movement in this association than in any other association. Greater potential sediment loss has been reported for western juniper communities compared to adjacent shrub steppe communities (Buckhouse and Mattison 1980). Davenport et al. (1998), however, concluded that pinyon-juniper contributed to accelerated erosion only on certain soil types. An increase in pinyon and juniper had little effect on sediment loss on soils with low erosion potentials but did increase soil loss where soils were highly erosive. They found plant cover in the tree interspace played an important role in reducing sediment loss on highly erosive soils.

\section{Climax}

Although a frequently debated ecological term, climax has often been applied to juniper and pinyon pine woodlands. McCune and Allen (1985) defined climax as "a relatively stable composition that develops in the absence of major disturbance". Since many woodlands exhibit very low dynamism, West and Van Pelt (1987) felt climax is a good working definition of a possible result of succession towards closed woodlands. Since the life span of western juniper can exceed 1,000 years (Miller et al. 1999b) it would appear that once a woodland has closed, the site will remain a woodland, in the absence of a major disturbance. However, major disturbance events that have shifted relatively stable closed woodlands to other steady states or seral stages are severe droughts in the Southwest (Bentancourt et al. 1993) and extreme fire conditions creating crown fires in dense pinyon-juniper woodlands (West 1999).

At climax, woodland structure and composition varied with site potential across the landscape. The 6 associations we sampled represent a major portion of the landscape heterogeneity. Western juniper cover and density in closed stands was as high as $90 \%$ and 1,731 trees $\mathrm{ha}^{-1}$ on aspen sites or as low as $19 \%$ and 64 trees ha ${ }^{-1}$ on low sagebrush sites (Table 3 ). The time

\begin{tabular}{|c|c|c|c|}
\hline Association & NO & N1 & $\mathrm{N} 2$ \\
\hline $\begin{array}{l}\text { Low sagebrush/Sandberg bluegrass } \\
\text { open }(n=5) \\
\text { closed }(n=4)\end{array}$ & $\begin{array}{l}35 \\
37\end{array}$ & $\begin{array}{l}8.4 \\
9.5\end{array}$ & $\begin{array}{l}5.9 \\
6.4\end{array}$ \\
\hline $\begin{array}{l}\text { Mountain big sagebrush/ } \\
\text { Thurber needlegrass } \\
\text { open }(n=5) \\
\text { closed }(n=6)\end{array}$ & $\begin{array}{l}45 \\
39\end{array}$ & $\begin{array}{r}10.6 \\
2.5\end{array}$ & $\begin{array}{l}7.2 \\
1.6\end{array}$ \\
\hline $\begin{array}{l}\text { Idaho fescue (Devils Garden) } \\
\text { open }(n=6) \\
\text { closed }(n=9)\end{array}$ & $\begin{array}{l}33 \\
38\end{array}$ & $\begin{array}{l}9.2 \\
4.0\end{array}$ & $\begin{array}{l}6.3 \\
2.4\end{array}$ \\
\hline $\begin{array}{l}\text { Idaho fescue (Steens Mt) } \\
\text { open }(n=9) \\
\text { closed }(n=6)\end{array}$ & $\begin{array}{l}43 \\
41\end{array}$ & $\begin{array}{l}10.7 \\
10.3\end{array}$ & $\begin{array}{l}6.2 \\
6.6\end{array}$ \\
\hline $\begin{array}{l}\text { Quaking aspen } \\
\text { open (9) } \\
\text { closed (4) }\end{array}$ & $\begin{array}{l}35 \\
35\end{array}$ & $\begin{array}{l}8.8 \\
8.9\end{array}$ & $\begin{array}{l}5.7 \\
5.7\end{array}$ \\
\hline
\end{tabular}




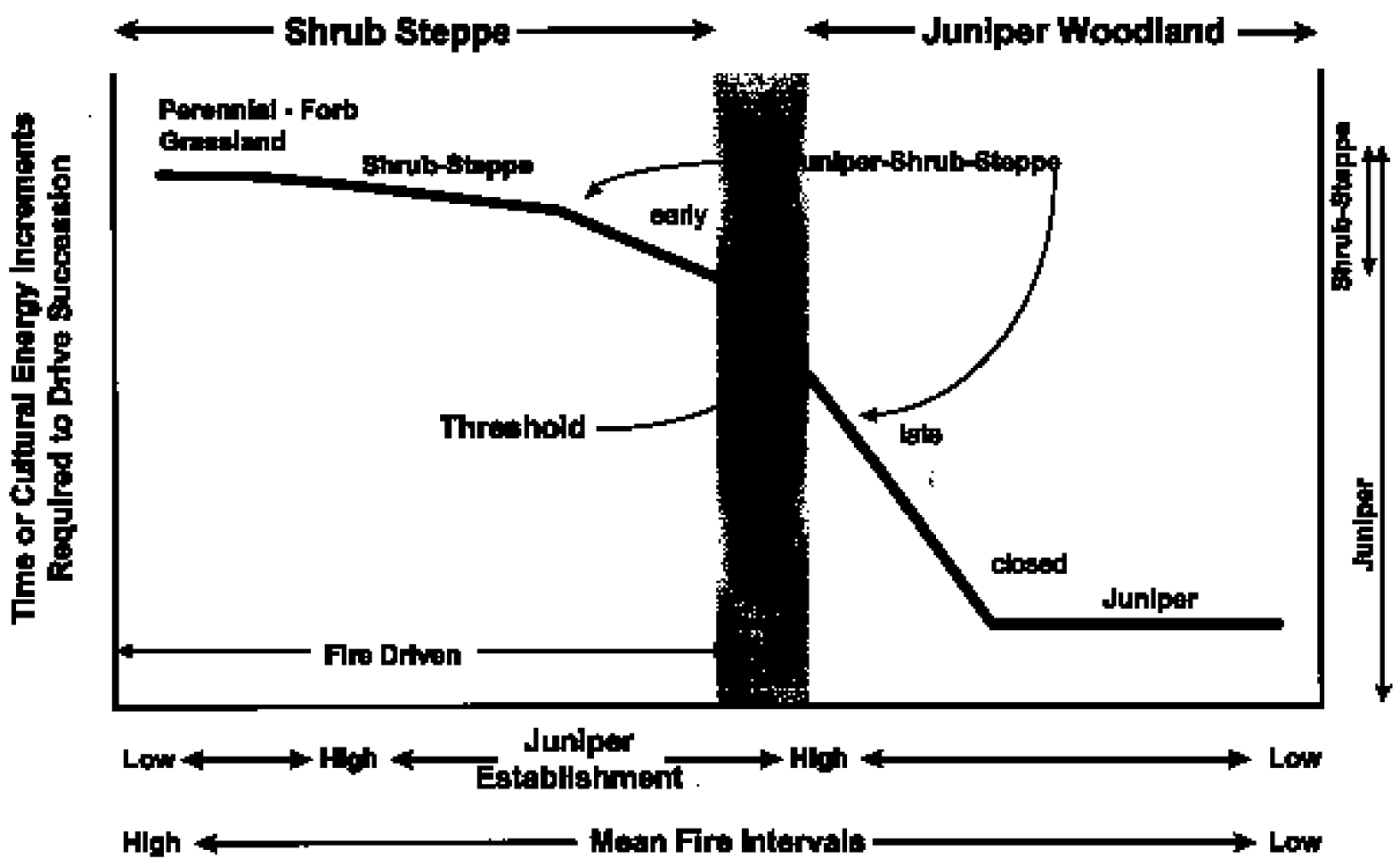

Fig. 6. Conceptual diagram of changes in a shrub steppe community in the absence of fire (modeled after Archer 1989). In the absence of fire the abundance of shrubs decline as juniper trees gain dominance. A threshold has been crossed when understory fuels drop to a level where fire is unlikely to carry through the stand or generate enough heat to kill trees $>3 \mathrm{~m}$ tall. The probability of the woodland crossing the threshold and reverting back to shrub steppe is very low in the absence of a major disturbance or very costly inputs. Tree establishment declines due to a decrease in seed input and safe sites provided by shrubs.

required for woodlands to reach a closed state is highly variable. The minimum time required for woodlands to develop a closed canopy was 60 to 70 years in a mountain big sagebrush/Idaho fescue community (Miller and Rose 1999). Nearly $80 \%$ of the trees established within a 30 year period. Minimum time period for juniper stand closure to occur in an aspen stand was 80 years (Miller and Rose 1995). We typically observed less annual ring width in juniper stems during the early stages of woodland succession in aspen compared to mountain big sagebrush associations. Although these sites are generally more productive, interspecific competition among trees is probably greater.

\section{Floristics and Diversity}

We encountered 335 vascular plant species in our macro plots in the High Desert and Klamath Ecological Provinces. In pinyon-juniper woodlands across Nevada and Utah, West (1984) found 367 vascular plants species. In a more recent study, which included more sites and woodlands in southern Nevada (bordering the Mojave Desert), West et al. (1998) reported nearly 500 species in pinyon juniper woodlands across Nevada. In our study, the contribution of perennial forbs was highly variable among and within associations and subgroups. Mean forb cover ranged between 1 and $16.5 \%$ among associations. On Steens Mountain, forbs accounted for a significant portion of the understory vegetation, while contributing $\leq 2 \%$ of the ground cover in northern California. Driscoll (1964) reported that forbs constituted a small portion of the understory in juniper woodlands in central Oregon. In open old growth western juniper woodlands in the pumice sand region of the Mazama Ecological Province (Fig.1), perennial forb cover typically varied around 1\% (Waichler et al. 2001).

The response of species diversity and richness to increasing juniper dominance varied among associations. During the transition from open to closed stands there was a decline in species number and richness in the mountain big sagebrush/Thurber needlegrass association, and a decline in richness in the mountain big sagebrush/Idaho fescue association in the Devils Garden area (Table 6). Removal of tree dominance in mountain big sagebrush/Thurber needlegrass association increased both species number and richness (Bates et al. 2000). They reported 45 plant species in tree removal plots compared to 25 on adjacent closed woodland plots. In the pinyon-juniper region plant species richness is usually minimal in closed woodlands (West et al. 1978, 1998). However, juniper dominance appeared to have little effect on either species number or richness in the other associations we studied.

\section{Management Implications and Conclusions}

The identification of spatial and temporal heterogeneity in western juniper woodlands is extremely important when evaluating potential resource problems, assessing wildlife habitat values, and developing management plans. As shrub steppe communities are converted to juniper woodlands, community structure, composition, function, disturbance patterns, and wildlife habitat are altered. The conceptual model presented in Figure 6 (derived from Archer 1989) illustrates the conversion of a mountain big sagebrush steppe community to a juniper woodland in the absence 
of fire. During the early phases of woodland development, transition is easily reversible with fire. By the mid to late stages of transition a threshold is crossed where the natural reversal to shrub steppe communities by fire is unlikely. As shrubs decline the probability of a fire intense enough to kill large juniper trees rapidly decreases. Juniper establishment declines with woodland maturity because of a decrease in seedling establishment sites as shrubs die out and an increase in intra-specific competition. On-site seed input also declines because of the loss of the fruit crop through increasing tree competition. As juniper woodlands close and mast crops and shrubs are lost (Miller and Rose 1995), fauna dependent on berries or shrubs also decline. Introduced weeds displacing native understory species represents a second potential threshold within this ecosystem. West (1999) separates juniper and pinyon systems into 2 phases: (1) trees do not dominate the open interspace where shrubs, grasses, and forbs control the microclimate and soils; and (2) trees dominate microclimates and soils across the major fraction of the matrix (including interspace). The threshold separating these 2 phases, savannas and woodlands, may be defined as the point where trees begin to influence the interspace causing changes in community structure (e.g. decline in shrubs) and community processes such as fire and water movement.

As community structure changes during woodland development, management options also change. Crossing an ecological threshold from shrub steppe to woodland not only results in a significant reduction in the role of fire, but depending on the site may result in the loss of native plant species and loss of soils. On the more arid sites in this study and in studies throughout the juniper and pinyon system, woodland development has led to desertification (West 1999) and reduction in site productivity (McDaniel and Graham 1992). Proper identification of the community and soils will indicate if the potential for these losses will be high or low with stand closure. In addition, the response of herbaceous understory to increasing juniper dominance may be influenced by past or current disturbance or the presence of introduced weeds. Structural characteristics described in Table 1 can help identify the woodland transitional state. Tree canopy cover and density alone are only of value if the maximum potential within an association has been defined.
In several of the plant associations we studied, the herbaceous understory cover remained intact as juniper dominance increased. This finding is counter to the results reported in much of the pinyonjuniper zone. However, the decline in understory we noted in the more arid big sagebrush associations is consistent with research from pinyon-juniper communities in Utah and Nevada (Arnold 1964, Blackburn and Tueller 1970, Meeuwig and Cooper 1981, Tausch et al. 1981, Everett and Sharrow 1985, Tausch and West 1995). Woodlands occupying more arid sites or soils with restrictive layers (e.g. petrocalcic or duric soil horizons) may be more prone to loss of understory. Both of these conditions may be similar to those found throughout the pinyon-juniper woodland alliance in the Intermountain Region. However, past and current overgrazing may also mask potential differences in herbaceous response to woodland development in the pinyon-juniper type. We and others (Dobrowolski, personal communication) have observed closed two needle pinyonUtah juniper woodlands in Utah on moderately deep soils with perennial grass cover exceeding $10 \%$ cover. Identifying factors that help predict herbaceous response during woodland development should be a research priority. Based on our results, 2 initial hypotheses can be proposed: (1) sites with restrictive layers loose understory cover during woodland development, and (2) some understory dominants (in our case Thurber needlegrass) are poor competitors with juniper, and will decline during woodland development.

To reduce the confusion in both the literature and on environmental issues related to juniper and pinyon woodlands, the spatial and temporal heterogeneity of the site or landscape in question should be identified when conducting inventories, research, or developing management plans, and classification schemes.

\section{Literature Cited}

Adams, A.W. 1975. A brief history of juniper and shrub populations in southern Oregon. Wild. Res. Rep. No. 6, Oregon State Game Commission, Corvallis, Ore.

Anderson, E.W., M.M. Borman, and W.C. Krueger. 1998. The ecological provinces of Oregon: a treatise on the basic ecological geography of the state. Ore. Agr. Exp. Sta. SR 990.

Archer, S. 1989. Have southern Texas savannas been converted to woodlands in recent history? Amer. Natur. 134:545-561.

Arnold, J.F. 1964. Zonation of understory vegetation around a juniper tree. J. Range Manage. 17:41-42.
Bailey, R.B. 1994. Description of the Ecoregions of the United States. USDA Forest Serv. Misc. Publ. 1391.

Barney, M. A. and N. C. Frischknecht. 1974. Vegetation changes following fire in the pinyon-juniper type of west-central Utah. J. Range Manage. 27:91-96.

Bates, J.D., R.F. Miller, and T. Svejcar. 1998. Understory patterns in cut western juniper (Juniperus occidentalis spp. occiden talis Hook.) woodlands. Great Basin Nat. 58:363-374.

Bates, J.D., R.F. Miller, and T. Svejcar. 2000. Understory vegetation response and nitrogen cycling following cutting of western juniper. J. Range Manage. 53:119-126.

Belsky, J.A. 1996. Viewpoint: western juniper expansion: Is it a threat to arid northwestern ecosystems? J. Range Manage 49:53-59.

Betancourt, J.L. E.A. Pierson, K.A. Rylander, J.A. Farichild-Parks, and J.S. Dean. 1993. Influence of history and climate on New Mexico pinon-juniper woodlands. pp. 42-62. In: E.F. Aldon and D.W. Shaw (tech. coord.), Managing pinon-juniper ecosystems for sustainability and social needs. USDA For. Serv. Gen. Tech. Rep. RM-236.

Blackburn, W.H. and P.T. Tueller. 1970. Pinyon and juniper invasion in black sagebrush communities in east-central Nevada. Eco. 51:841-848.

Buckhouse, J.C. and J.L. Mattison. 1980. Potential soil erosion of selected habitat types in the high desert region of central Oregon. J. Range Manage. 33:282-285.

Burkhardt, J.W. and E.W. Tisdale. 1969. Nature and successional status of western juniper vegetation in Idaho. J. Range Manage. 22:264-270.

Burkhardt, J.W. and E.W. Tisdale. 1976. Causes of juniper invasion in southwestern Idaho. Ecol. 57:472-484.

Cottom, W. P. and G. Stewart. 1940. Plant succession as a result of grazing and of meadow desiccation by erosion since settlement in 1892. J. For. 38:613-626.

Cronquist, A., A.H. Holmgren, N.H. Holmgren, J.L. Reveal, and P.K. Holmgren. 1977. Intermountain flora. New York Botanical Garden, Bronx N.Y.

Davenport, D.W., Breshears, D.D., Wilcox, B.P., Allen, C.D. 1998. Viewpoint: Sustainability of pinyon-juniper ecosystems - a unifying perspective of soil erosion thresholds. J. Range Manage. 51:231-240.

Driscoll, R.S. 1964. Vegetation-soil units in the central Oregon juniper zone. USDA For. Ser. Res. Pap. PNW-19.

Evans, R.A. and J.A. Young. 1985. Plant succession following weed control of western juniper (Juniperus occidentalis) with Picloram. Weed Sci. 33:63-68.

Everett, R.L. and S.H. Sharrow. 1985. Response of grass species to tree harvesting in singleleaf pinyon-Utah juniper stands. USDA For. Ser. Res. Pap. INT-334.

Franklin, J.F. and C.T. Dyrness. 1988. Natural vegetation of Oregon and Washington. Oregon State Univ. Press. 
Gauch, J.G. Jr. 1982. Multivariate analysis in community ecology. Cambridge University Press, New York, N.Y.

Gedney, D.R., D.L. Azuma, C.L. Bolsinger, and N. McKay. 1999. Western juniper in eastern Oregon. USDA For. Ser. PNW-GTR-464.

Gee, G.W. and J.W. Bauder. 1986. Particle size analysis, p. 383-411. In: A. Klute (ed.). Methods of soil analysis Part 1, Physical and mineralogical methods. ASA and SSSA Madison Wisc.

Grossman, D.H., D. Faber-Langendoen, A.S. Weakley, M. Anderson, P. Bourgeron, R. Crawford, K. Goodin, S. Landaal, K. Metzler, K. Patterson, M. Pyne, M. Reid, and L. Sneddon. 1998. International classification of ecological communities: terrestrial vegetation of the United States. The Nature Conservancy.

Hitchcock, C.L. and A. Cronquist. 1973. Flora of the Pacific Northwest. Univ. Washington Press, Seattle, Wash.

Maser, C. and J.S. Gashwiler. 1978. Interrelationships of wildlife and western juniper. p. 37-82. In: Proc. Western Juniper Ecology and Management workshop. USDA For. Serv. Gen. Tech. Rep. PNW-74.

McCune, B. and T.F.H. Allen. 1985. Forest dynamics in the Bitterroot Canyons, Montana. Can. J. Bot. 63:377-383.

McDaniel, P.A. and R.C. Graham. 1992. Organic carbon distributions in shallow soils of pinon-juniper woodlands. Soil Sci. Soc. Amer. J. 56:499-504.

Meeuwig, R.O. and S.V. Cooper. 1981. Site quality and growth of pinyon-juniper stands in Nevada. For. Sci. 27:593-601.

Miller, R. F. and J. A. Rose. 1995. Historic expansion of Juniperus occidentalis (western juniper) in southeastern Oregon. Great Basin Natur. 55:37-45.

Miller, R.F and J.A. Rose. 1999. Fire History and western juniper encroachment in sagebrush steppe. J. Range Manage. 52:550-559.

Miller, R. F. and P. E. Wigand. 1994. Holocene changes in semiarid pinyon-juniper woodlands. BioSci. 44:465-474.
Miller, R.F., T. Svejcar, and J.A. Rose. 1999a. Conversion of shrub steppe to woodland. p. 275-284. In: Monsen, S.B., S Richards, R.J. Tausch, R.F. Miller, C. Goodrich, (comp.); Proc.-Ecology and Management of Pinyon-Juniper Communities Within the Interior West. USDA For. Ser., RMRS-P-9.

Miller, R.F., R. Tausch, and W. Waichler. 1999b. Old-growth juniper and pinyon woodlands. p. 285-390. In: Monsen, S.B., S. Richards, R.J. Tausch, R.F. Miller, C. Goodrich, (comp.); Proc.-Ecology and Management of Pinyon-Juniper Communities Within the Interior West. USDA For. Ser., RMRS-P-9.

Poulton, C.E. and E.W. Tisdale. 1961. A quantitative method for the description and classification of range vegetation. J. Range Manage. 14:13-21.

Puchy, C.A. and D.B. Marshall. 1993. Oregon wildlife diversity plan. Oregon Dept. of Fish and Wildl., Portland, Ore.

SAS. 1996. SAS-STAT user's guide. SAS Institute, Inc., Cary, N.C.

Tausch, R.J. and N.E. West. 1995. Plant species composition patterns with differences in tree dominance on a southwestern Utah Pinon-Juniper site. p. 16-23. In: Desired Future Conditions for Pinon-Juniper Ecosystems. USDA For. Ser. Gen. Tech. Rep. RM-258.

Tausch, R.J., N.E. West, and A.A. Nabi. 1981. Tree age and dominance patterns in Great Basin pinyon-juniper woodlands. J. Range Manage. 34:259-264.

Taylor, G.H. 1993. Normal annual precipitation; state of Oregon. Oregon Climate Service, Oregon State Univ., Corvallis, Ore.

Tress, J.A. Jr. and J.M. Klopatek. 1987. Successional changes in community structure of pinyon-juniper woodlands in north-central Arizona. p. 80-85. In: Everett, R.L. (compiler). Proc.-Pinyon Juniper Conf. USDA For. Serv. Gen. Tech. Rep. INT-215.

USDI-BLM. 1990. The juniper resources of eastern Oregon. USDA, BLM. Infor. Bull.
Vaitkus, M.R. and L.E. Eddlemen. 1991. Tree size and understory phytomass production in a western juniper woodland. Great Basin Natur. 51:236-243.

Waichler, W.S., R.F. Miller, and P.S. Doescher. 2001. Community characteristics of old-growth western juniper woodlands in the pumice zone of central Oregon. J.Range Manage. (accepted).

Wall, T.G. 1999. Western juniper encroachment into aspen communities in the northwest Great Basin. M.S. Thesis Oregon State University, Corvallis, Ore.

West, N.E. 1984. Successional patterns and productivity potentials of pinyon-juniper ecosystems. p.1301-1332. In: Developing strategies for rangeland management. Nat. Res. Counc./Nat. Acad. of Sci.. Westview Press, Boulder, Colo.

West, N.E. 1999. Juniper-Pinon savannas and woodlands of western North America. pp. 288-308 In: R.C. Anderson, J.S. Fralish, and J.M. Gaskin, eds. Savannas, barrens, and rock outcrop plant communities of North America. Cambridge Univ. Press.

West, N.E. and N.S. Van Pelt. 1987. Successional patterns in pinyon-juniper woodlands. p. 43-52. In: Everett, R.L. (compiler). Proc.-Pinyon Juniper Conf. USDA For. Serv. Gen. Tech. Rep. INT-215.

West, N.E., R.J. Tausch, and P.T. Tueller. 1998. A management-oriented classification of pinyon-juniper woodlands of the Great Basin. USDA For. Serv. RMRS-GTR-12.

West, N.E., R.J. Tausch, K.H. Rea and P.T. Tueller. 1978. Phytogeographical Variation Within Juniper-Pinyon Woodlands of the Great Basin. Great Basin Natur. Mem. 2:119-136

Young, J.A., R.A. Evans, and C. Rimbey. 1985. Weed control and revegetation following western juniper (Juniperus occidentalis) control. Weed Sci. 33:513-517. 